\title{
Household Labor Supply and Welfare Participation in Sweden
}

\author{
Lennart Flood ${ }^{1}$ \\ Jörgen Hansen ${ }^{2}$ \\ Roger Wahlberg ${ }^{3}$ \\ Working Papers in Economics no 18 \\ 1999-11-28 \\ (Preliminary version)
}

\begin{abstract}
:
Using a sample of Swedish households, we estimate a household labor supply model assuming that preferences for consumption and leisure can be described by a direct translog utility function. The labor supply and welfare participation decisions are treated as a discrete choice problem, and we assume that these choices follow a simple conditional logit rule. In addition, we allow unobserved individual-specific effects to be correlated across alternatives. We assume that these unobserved effects are drawn from a discrete distribution, and the correlation across alternatives is modeled using factor-loading techniques. Classification error in hours is allowed for by using a multiplicative measurement error specification. The estimates from the structural model yield inelastic labor supply among husbands and positive wage elasticity for wives. Further, the cross elasticities are close to zero.
\end{abstract}

Key words: Labor Supply, Welfare Participation, Unobserved Heterogeneity, Factor Loading, Tax Simulation.

JEL classification: J22

\footnotetext{
${ }^{1}$ Department of Economics, Göteborg University, Box 640, SE 40530 Göteborg email: Lennart.Flood@economics.gu.se Tel +46 31-7731331

${ }^{2}$ IZA, P.O. Box 7240, D-53072 Bonn, Germany e-mail hansen@iza.org

${ }^{3}$ Department of Economics, Göteborg University, Box 640, SE 40530 Göteborg email: Roger.Wahlberg@economics.gu.se Tel +46 31- 7731328
} 


\section{Introduction}

As a result of increased labor mobility in the European community, the study of incentive effects of taxes and transfer systems has again become an important topic for economic research ${ }^{4}$. Increased mobility makes it costly to maintain tax systems that differ substantially across nations. Since progressive tax systems normally tax skilled workers' income more than low skilled workers' and since skilled workers are presumably more mobile, tax system competition could lead towards a common proportional European tax system. From this perspective, it is therefore important to study the effects of moving from a progressive income tax system, such as the Swedish, towards a less progressive tax system. To accomplish this, we need to specify a structural model of labor supply.

The traditional way to model labor supply assumes that the decision variable, hours of work, is continuous and unconstrained. However, it has been shown that this framework need to impose restrictive conditions in order to be statistical coherent, see for instance MaCurdy et al (1990). Further, one underlying assumption in the traditional labor supply model is that the individual (or household) budget set is convex. Hence, to estimate such a model, a number of important simplifications of the income tax and transfer system must be imposed.

As an alternative to the continuous hours of work model, van Soest (1995), Hoynes (1996), Keane and Moffit (1999) and Blundell et al (1999) has suggested the use of a discrete choice model instead. In this framework, it is straightforward to

\footnotetext{
${ }^{4}$ A recent study that evalutes the effects of a flat tax in three different countries is given in Ström et.al (1999)
} 
include as many details as possible regarding the budget set. It further extends naturally into a household model, where husbands and wives jointly determine their labor supply. A disadvantage with this approach is the introduction of a classification error in hours of work. This error arises because of the aggregation of a continuum of hours of work into a finite number of classes. However, by using a multiplicative measurement error specification, following MaCurdy et al (1990) and Hoynes (1996), we can reduce this problem. ${ }^{5}$

In this study, we specify a structural model of discrete household labor supply along the lines described above. We also incorporate the decision of whether or not to participate in a social assistance program into the decision set. The reason for incorporating this into the model is that there has been a dramatic increase in the expenditure on social assistance in Sweden during the last decade. ${ }^{6}$ According to the National Board of Health and Welfare, total real expenditures between 1983 and 1997 increased from 4.4 billion Swedish kronor (SEK) to 12.4 billion SEK.

The empirical part is based on a sample of households drawn from the Swedish Household Income Survey (HINK), which contains very detailed income information supplied by the tax registers. As a consequence, this study differs from most previous studies since almost all relevant details in the tax and transfer systems are considered. To evaluate the budget set at different combinations of hours of work in the household, we use a micro simulation model (FASIT) developed by Statistical Sweden and the Swedish Ministry of Finance.

\footnotetext{
${ }^{5}$ Note also that there is no simple way to determine the appropriate number of classes. But according to both van Soest (1995) and Hoynes (1996), the main results seem to be rather insensitive regarding number of classes.

${ }^{6}$ The term social assistance is used synonymously with public assistance and welfare in this paper.
} 
We choose to present our results in terms of simulated wage and income responses, but we also use the estimates from the model to evaluate the effects of a policy simulation. Specifically, the effects of a reduction in the marginal tax rate among high-income earners will be evaluated using a micro simulation method. In addition to reporting the effects on hours of work and on consumption, we also report the overall welfare effects of the tax cut using an equivalent variation measure.

The result from the policy simulation indicates that moving from a progressive income-tax system towards a proportional system may have considerable welfare effects. Because of the structure of the reform, the welfare effects differ substantially across households, with the largest effects found for rich households. However, the predicted effect on hours of work is quite small and tax revenues are predicted to decrease significantly.

The remainder of this paper is organized as follows. Section II gives a detailed description of the budget set and the relevant benefit programs. Section III presents the economic model and Section IV describes the data used in the analysis. In Section V we present the results, while the conclusions are found in Section VI.

\section{The Budget Set}

A static model of household labor supply is assumed where spouses determine hours of work and consumption by maximizing a utility function $\mathrm{U}\left(\mathrm{C}, \mathrm{h}_{\mathrm{h}}, \mathrm{h}_{\mathrm{w}}\right)$ subject to the following budget constraint:

$C=C_{h}+C_{w}+B$

where $\mathrm{C}_{\mathrm{h}}$ and $\mathrm{C}_{\mathrm{w}}$ are husband's and wife's after tax income, respectively, and $\mathrm{B}$ is the amount of household specific means-tested benefits/subsidies. The individual components to total consumption are given as: 
$C_{i}=W_{i} h_{i}+Y_{i}+V_{i}-t\left(I_{i}\right) \quad \mathrm{i}=\mathrm{h}, \mathrm{w}$

where

$\begin{array}{lll}\mathrm{W}_{\mathrm{i}} & =\text { Gross wage per hour } \\ \mathrm{h}_{\mathrm{i}} & = & \text { Hours of market work per year } \\ \mathrm{Y}_{\mathrm{i}} & = & \text { Taxable nonlabor income per year } \\ \mathrm{V}_{\mathrm{i}} & = & \text { Non taxable nonlabor income per year } \\ \mathrm{t} & = & \text { Taxes determined by the function } \mathrm{t}(\cdot) \\ \mathrm{I}_{\mathrm{i}} & = & \text { Taxable income per year, } \mathrm{I}_{\mathrm{i}}=\mathrm{W}_{\mathrm{i}} \mathrm{h}_{\mathrm{i}}+\mathrm{Y}_{\mathrm{i}}-\mathrm{D}_{\mathrm{i}} \\ \mathrm{D}_{\mathrm{i}} & = & \text { Deductions per year }\end{array}$

The two major transfer programs included in $\mathrm{B}$ are: housing allowance $\left(\mathrm{B}_{\mathrm{h}}\right)$ and social assistance $\left(\mathrm{B}_{\mathrm{w}}\right){ }^{7}$ Housing allowance is determined by nationwide rules and is mainly directed toward families with children. About $9.1 \%$ percent of all families with children are eligible for housing allowance. The amount received by a household is determined by: net household income, housing expenditures, number of children and the ages of the spouses.

The rules determining social assistance are based on rather complicated systems and they also differ across municipalities. For each municipality and each type of family, we calculated a "norm" (the minimum level of disposable income to qualify for welfare) based on information provided by the Swedish municipalities. The amount of social assistance a family receives is simply the difference between the norm and the household's disposable income.

\footnotetext{
${ }^{7}$ When constructing the budget sets, we also include information about childcare costs.
} 
A detailed treatment of the income tax and benefits systems generally results in non-convex budget sets. This is also the case in Sweden, and to illustrate this, we show the household budget sets for two typical households in Figure 1. The budget sets are evaluated at 49 discrete points (seven for each spouse) ranging from 0 to 3,000 hours per year. The upper left-hand panel shows the budget sets for the husband conditional on different hours for his wife, while the lower left-hand panel shows similar information for the wife. The non-convexity of the budget sets at lower hours of work is apparent. The return to low hours of work (from 0 to 500 hours) varies substantially depending on spouse hours. If the spouse does not work, the budget set is flat for the household. The reason for this is that, at low earnings, the household is entitled to welfare and there is a $100 \%$ marginal tax rate on welfare. For the wife there is a very small return from an increase to 1,000 hours per year if the husband work few hours. The main reason for this pattern is the reduction in housing allowance associated with the increase in household income.

The budget set for a high-income family looks quite different. The non-labor income of this family is too high to enable them for welfare even if none of them work. However, the shape of the budget set is affected by both child-care costs and housing allowance. In the case where none of the spouses work, this family is entitled to 32,000 SEK in housing allowance and the cost of child-care ( 2 children) is 6,500 SEK. Due to a high wage rate, the housing allowance is reduced to zero already at 1,000 hours for the wife, regardless of the husband's hours of work. The cost of childcare reaches its maximum $(18,000)$ at a household income of about 300,000 SEK. From these illustrations it follows that it is mainly low-income households who face non-convex budget sets and high marginal effects. 
The main source for the non-convex budget sets is the generous transfer system designed to equalize the income distribution. However, income-tax system also produce non-convexities, but not as large as those produced by the benefit systems. To illustrate this, we show the marginal and average income tax rates as of 1993 in Figure 2. According to the original design of the 1991 Swedish tax reform, the income-tax system should only have two tax-brackets. The first for incomes below the break point with a tax rate equal to the municipal tax rate, and the second for incomes above this threshold with a tax rate equal to the municipal tax rate plus an additional 20 percent state tax rate. However, before the reform was launched it was decided to add an income dependent basic deduction and this explains the holes in the low-income interval.

\section{Economic Model and Empirical Specification}

We assume that each household chooses husband's hours of work $\left(\mathrm{h}_{\mathrm{h}}\right)$, wife's hours of work $\left(h_{w}\right)$, consumption $(C)$, and welfare $\left(d_{w}=1\right.$ if the household receives welfare and 0 otherwise) by maximizing a utility function given the budget set in (1).

Following van Soest (1995), a translog specification of the direct utility function is used, and for any specific household we have:

$$
\begin{aligned}
U\left(C, h_{h}, h_{w}\right)= & \beta_{C} \log (C)+\beta_{h} \log \left(H-h_{h}\right)+\beta_{w} \log \left(H-h_{w}\right)+ \\
& \beta_{C C}(\log (C))^{2}+\beta_{h h}\left(\log \left(H-h_{h}\right)\right)^{2}+\beta_{w w}\left(\log \left(H-h_{w}\right)\right)^{2}+ \\
& 2 \beta_{C h} \log (C) \log \left(H-h_{h}\right)+2 \beta_{C w} \log (C) \log \left(H-h_{w}\right)+2 \beta_{h w} \log \left(H-h_{h}\right) \log \left(H-h_{w}\right) \\
& -\phi d_{w}
\end{aligned}
$$

where it is assumed that the disutility from welfare participation $\left(\mathrm{d}_{\mathrm{w}}\right)$ is separable from the utility of leisure and consumption (Moffit (1983) and Hoynes (1996)). The 
disutility from welfare is included to account for nonparticipation among eligible families.

The total endowment of time $(\mathrm{H})$ is set to 4,000 hours/year. ${ }^{8}$ As mentioned above, the husband and wife are assumed to choose among seven different working states, respectively, ranging from zero up to 3,000 hours/year. Hence, for the household there are altogether 49 different hour's combinations.

The flexible specification in equation (2) does not automatically fulfill the quasi-concavity conditions. However, these conditions can be tested ex post. This contrasts a continuous model in which quasi-concavity has to be imposed a priori in order to guarantee model coherency.

In order to implement the model, we also have to specify the nature of heterogeneity in household preferences and the stochastic disturbances. Heterogeneity in preferences for leisure is introduced as

$$
\beta_{h}=\sum_{i=1}^{k} \beta_{h i} x_{h i}+\theta_{h}
$$

$$
\beta_{w}=\sum_{i=1}^{k} \beta_{w i} x_{w i}+\theta_{w}
$$

where the x-variables consists of observed individual and family characteristics, such as education, age, household composition, and region of living. The $\theta^{\prime}$ s represents unobserved variables that affect preferences for leisure. It is reasonable to assume that an important source for population heterogeneity in terms of preferences for leisure is

\footnotetext{
${ }^{8} \mathrm{H}$ can also be regarded as a parameter that can be estimated together with all other parameters. van Soest (1995) reports that the results are insensitive towards the choice of $\mathrm{H}$.
} 
unobserved. In order to account for this, we formulate a finite mixture model, which allows for unobserved heterogeneity in a very flexible way without imposing a parametric structure. This idea of incorporating unobserved heterogeneity origins from Heckman and Singer (1984) and there exist a number of applications in duration data (Ham and Lalonde (1996)), count data (Deb and Trivedi (1997)), and labor supply (Hoynes (1996)). Heckman and Singer (1984) also showed that estimation of finite mixtures might provide a good discrete approximation even if the underlying distribution is continuous.

To be specific, we assume that there exist $\mathrm{M}$ different $\left(\theta_{\mathrm{hj}}, \theta_{\mathrm{wj}}\right)$ pairs that determine the spouses preferences, each observed with probability $\pi_{j}$ (where $\pi_{j}>0$ and $\left.\Sigma \pi_{\mathrm{j}}=1\right)$. This specification allows for arbitrary correlation between the husbands and wives labor supply and independence can be tested. The interpretation of these unobserved heterogeneity parameters are straightforward, and a high value simply implies a high preference for leisure.

The specification of welfare participation takes the form

$$
\phi=\mu+\sigma_{h} \theta_{h j}+\sigma_{w} \theta_{w j} \quad \mathrm{j}=1, \ldots, \mathrm{M}
$$

where $\mu$ and $\sigma^{\prime}$ s are parameters to be estimated. This specification is very general and allows for correlation between the spouses' preference for work and welfare. This way of allowing for correlation across alternatives is based on factor loading technique, see for instance Ham and Lalonde (1996). 
Adding an additive error term to the utility function in equation (2), drawn from the extreme value distribution, results in the conditional logit model. ${ }^{9}$ The contribution to the likelihood function for a given household (i', j',k') becomes

$$
\left(p \mid \theta_{h}, \theta_{k}\right)_{i^{\prime} j^{\prime} k},=\frac{\exp \left(U_{i{ }^{\prime} j^{\prime} k^{\prime}}\right)}{\sum_{i, j, k} \exp \left(U_{i j k}\right)}
$$

where $\mathrm{i}$ and $\mathrm{j}$ indicates husbands and wife's hours, respectively, and $\mathrm{k}$ indicates welfare participation. This expression simply denotes the probability that the utility in the observed state is the highest amongst all possible hours and welfare combinations. In our specification of measurement errors or classification error, we follow MaCurdy et al (1990) and Hoynes (1996), and assume a multiplicative classification error structure. Let $\mathrm{H}_{h}$ and $\mathrm{H}_{\mathrm{w}}$ denote reported hours and $\mathrm{h}_{\mathrm{h}}$ and $\mathrm{h}_{\mathrm{w}}$ optimal (discrete) hours. The multiplicative classification error specification is given as

$$
H_{i}=h_{i} e^{\varepsilon_{i}} \quad \text { with } \varepsilon \sim N\left(-\frac{1}{2} \sigma_{i}^{2}, \sigma_{i}^{2}\right) \quad \text { for } \mathrm{i}=\mathrm{h}, \mathrm{w}
$$

Thus, zero hours are observed with certainty but when optimal hours are positive they differ from reported hours by a factor of proportionality.

In presence of unobserved heterogeneity and classification errors, the contribution to the likelihood is given by

\footnotetext{
${ }^{9}$ Alternatively, we could assume that the errors were drawn from a normal distribution. However, this would require evaluation of high-dimensional integrals, which would be intractable in our framework. Recall that we assume that each household chooses among 98 different state combinations. We also believe that the restrictiveness with the extreme value distribution is smaller when we incorporate unobserved heterogeneity for reasons already discussed.
} 
(7) $\quad l=\sum_{m=1}^{M} \pi_{m}\left(\left(p \mid \theta_{h m} \theta_{m}\right)_{i^{\prime},{ }^{\prime}}, g_{h} g\right) \delta_{i^{\prime} j^{\prime}}$,

where $\delta_{i^{\prime} j^{\prime} k}$ 'is an indicator for the observed state for each household, and $g_{h}$ and $g_{w}$ are densities for measurement error for the husband and wife. The assumptions presented in (6) implies

$$
g_{i}=\left\{\begin{array}{c}
1 \quad \text { if } \mathrm{H}_{\mathrm{i}}=0 \text { or } \mathrm{h}_{\mathrm{i}}=0 \\
\frac{1}{\sigma_{i}} \phi\left(\frac{\left[\log \left(H_{i}\right)-\log \left(h_{i}\right)\right]+\frac{1}{2} \sigma_{i}^{2}}{\sigma_{i}}\right) \text { else } \quad \mathrm{i}=\mathrm{h}, \mathrm{w}
\end{array}\right.
$$

\section{Data}

The data used in the empirical analysis are drawn from the 1993 cross-section of the Swedish Household Income Survey (HINK) supplied by Statistics Sweden. HINK provides information on labor market activities and incomes for a random sample of Swedish households.

In order to obtain the sample of interest, several selections have been imposed. To start with there is 6,642 households of married/cohabitant spouses. From this the following exclusions have been done; spouses younger than 18 or older than 64, students, early retired or own employed and finally a few extreme outliers in hourly wages. After these selections the resulting sample size is 3,488 households.

Information about yearly hours of work is based on survey questions and the hourly wage rate is obtained by dividing gross labor income by yearly hours of work. 
Non-labor income contains income from capital gains and public transfers such as unemployment insurance and different allowances. Non-labor income is divided in two parts, taxable and non-taxable. Taxable non-labor income consist of: car or expense allowance, job-related injury compensation, rehabilitation compensation, training allowance for labor market training, daily allowance in the case of unemployment, cash labor-market support and other taxable transfers. The main component in non-taxable non-labor income is child allowance, which every family with a child below the age of 16 receives.

Deductions consist of several components: deductions for business expenses, general deductions for retirement insurance, general deductions for periodical supports and loss related deductions. The precision in this variable is a good illustration of the advantage of using register data. It is difficult to obtain a reliable measure of deductions from a survey. Of course all errors in the income variables would lead to errors in the imputed budget set. It is therefore crucial to have income data of a high quality in studies of labor supply and taxes.

In Table 1 we present sample statistics for the variables used in this study. Hours of work refer to annual hours and the reported average values are 1,845 for males and 1,520 for females. It is an well-established fact that the participation rates in Sweden are high, both for men and women. This is confirmed in our data where 94 percent of the men performed market work and 92 percent of the women. The distribution of working hours is presented in Figure 3. The husband's hours are concentrated at 40 hours per week whereas there is much more variation in the wife's hours.

The mean hourly wage is 119 SEK for males and 91 SEK for females. For non-workers the wage rates were imputed using regression methods. A standard 
Mincer-type of wage equation was estimated separately for males and females. Explanatory variables included in the wage equations are: years of actual work experience and its square, dummy variables for region of living, education and age. The regression results are presented in Table 6.

Education is measured by three dummy variables corresponding to the highest degree the individual has obtained: primary school, high school or university. The level of education is quite similar for both spouses. About 60 percent have a high school degree and about 15 percent have a university degree. Since there is substantial variation in regional unemployment, three dummies identifying region of living were included: major cities, medium cities and other areas. A dummy variable for presence of (at least) a child younger than 7 and the number of children less than 17 years old were also included as explanatory variables. About one third of the households have a pre-school child (less than 7 years).

Finally, a measure of welfare participation was included. For our sample a small share, about 3 percent, of all households received welfare during 1993. A household was defined as a welfare recipient if it received some assistance for at least one month during the year. It should be noted that most of the households that received welfare in this sample only received it for a short period. Of all the welfare recipients, about 50 percent received it for three months or less and about 20 percent for more than seven months.

\section{Results}

The estimated parameters of our structural model are presented in Table 2. We present estimates for two specifications, one that excludes welfare and one where welfare participation is modeled jointly with the household labor supply. From Table 
2 it follows that the estimates for both specifications are similar, and consequently, we only discuss the results based on the full structural model with welfare. At these estimates the utility function fulfills the conditions for quasi-concavity for all households, evaluated at observed hours and consumption. Since there is a fair amount of variation in both hours and consumption, this means that the utility function is concave over a large region. Further, since the estimated utility function fulfills the theoretical requirements it can be used for predictions and simulation.

The first set of estimates in Table 2 refers to husband's preference for leisure and the second set to the wife's. As expected, presence of children has a strong negative effect on female work preferences and a much smaller effect on males. The effect of region is completely different for males and females. The effect is estimated with relatively high precision for both spouses and the result indicates higher preference for work in large cities (the reference case Stockholm, Gothenburg or Malmo) for males but lower preference for females.

University education has a strong significant effect for both spouses. Highly educated females have stronger preference for work whereas the opposite holds for males. The estimated age effects indicate that the preference for leisure is highest in the oldest age group (the reference group age 56-64).

All $\beta$-estimates with respect to consumption and leisure are estimated with a high precision. The combined effects of these estimates can be expressed in terms of marginal utility of leisure and consumption. The marginal utility with respect to husband leisure is given as:

$$
U_{h}=\frac{\beta_{h}+2 \beta_{h h} \log \left(H-h_{h}\right)+2 \beta_{C h} \log (C)+2 \beta_{h w} \log \left(H-h_{w}\right)}{H-h_{h}}
$$


and the marginal utilities for wife's leisure and consumption are given by similar expressions. In order to evaluate the marginal utilities, values for $\beta_{\mathrm{h}}$ and $\beta_{\mathrm{w}}$ are needed. Evaluated at sample means and weighted by the $\pi$-values, the coefficients in Table 2 implies that $\beta_{\mathrm{h}}=40.09$ and $\beta_{\mathrm{w}}=25.65$. Further, evaluated at the sample mean of $\left(H-h_{h}\right),\left(H-h_{w}\right)$ and $C$, the computed marginal utilities are $U_{h}=-3.99, U_{w}=2.23$ and $\mathrm{U}_{\mathrm{C}}=5.45$. As expected, the marginal utility of female leisure is above the corresponding male value.

The first estimated pair of support points $\left(\theta_{\mathrm{h} 1}=68.94\right.$ and $\left.\theta_{\mathrm{w} 1}=23.47\right)$ identifies households where the husband has a high preference for leisure and the wife a low preference. The estimated probability $\left(\pi_{1}=0.12\right)$ indicates that about 12 percent of the sample belongs to this category. The majority, 78 percent, of the households belongs to the second group where both spouses have a low preference for leisure. The third group is households where the husband has a low preference for leisure and the wife a high preference and about 7 percent of the sample belongs to this group. The final identified category is households where both spouses have high preference for leisure and about 3 percent of the sample belongs to this group.

The last set of results reported in Table 2 refers to the disutility of welfare. The constant, $\mu$, indicates that there is a positive and significant stigma effect. Thus, welfare participation lowers the utility level of the household. The estimated loading parameters indicate a negative correlation between welfare and unobserved elements of work effort. Similar to the results reported in Hoynes (1996), this correlation is also higher for the females work effort. The estimated negative covariance between welfare and labor supply can be taken as support for the hypothesis of self-selection into welfare. 
The effects of wage and income changes are assessed using simulations. Specifically, income and wages were increased by 1 percent and the resulting changes in predicted working hours were calculated. The results in Table 3 imply that working hours are quite insensitive for income and wage changes, especially for males. For instance, an increase in husbands wages by 1 percent (everything else constant) do not increase his working hours at all while wives hours of work decrease with 0.02 percent. The corresponding results for wives show an increase in hours by 0.12 percent, but no effect on husband's hours. The estimated income effects are negative but close to zero.

In order to evaluate the influence of the stigma effect on labor supply we performed an experiment where the norm was increased by 10 percent. In the model without welfare, labor supply decreased with 0.02 percent for males and with 0.05 percent for females. The corresponding results for the model including welfare were 0.03 percent and 0 percent, respectively.

A well-known problem in labor supply models is poor ability to fit observed distribution of hours of work. One approach to improve the fit of these models is to include controls for fixed costs of work, see Kapteyn et al (1990) and van Soest (1995. In our approach, the estimated support points are used in the calculation of predicted hours of work. This produces a distribution of hours rather similar to the observed one as can be seen from Figure 3. The upper panel shows the observed and predicted distributions for husbands. The results indicate an almost exact replication of the frequency of non-workers, the observed frequency is about 6 percent and the predicted about 5 percent. The peak in the distribution, around 2,500 hours per year, is however overestimated. About 85 percent of the husbands belong to this category according to our predictions, whereas only 75 percent are observed in that class. 
The lower panel of Figure 3 displays the corresponding distribution of hours of work for women. As expected, there is more variation in working hours. Our model is actually able to capture this increased variation quite well. For instance, the predicted frequencies of non-workers match the observed frequencies almost exactly.

The final results discussed here refer to a policy simulation. In order to evaluate the effect of moving from a progressive tax system towards a proportional one, we simply drop the federal tax rate of 20 percent above the break point. As a result of the simulated tax change, working hours increase on average by 1.6 percent for wives and by 0.26 percent for husbands. The resulting increase in disposable income is 7.6 percent and the decrease in tax revenues is almost 14 percent. Thus, despite the fact that relatively few females have earnings above the breakpoint the change in female hours is still larger than for males. In fact only 1 percent of the males and 5.8 percent of the females change their working hours. This is a natural consequence of the discrete approach of modeling labor supply where the dominating prediction is no change in working hours.

A more detailed listing of the result for the whole sample is given in Table 4. This table also presents the welfare effects of the tax reform. We chose equivalent variation (EV) as our money metrics of a welfare change. $\mathrm{EV}$ is measured as the amount of money added or subtracted from the households' disposable income under the initial tax rules in order to make the household indifferent between the initial and the alternative tax system. As such, EV summarizes the household's net welfare change associated with behavioral responses. As mentioned above, in our simulation the majority of the household members do not change their working hours and in these cases EV just measure the change in disposable income before and after the tax change. 
The average EV for the whole sample is 25,200 SEK. However, there is a substantial variation across the households. Table 5 lists EV for different levels of household disposable income. All EV-values are non-negative which suggests that there are welfare gains from the tax change. However, there are dramatic differences in EV depending on the level of household income. The estimated average EV for the poorest 10 percent is 6,455 SEK/year compared to 90,510 SEK/year for the richest 10 percent. The gain from the simulated tax reform is quite small evaluated for all households below the median. The calculated mean EV below the median is only 7,610 SEK compared to 63,224 SEK above the third quartile.

To summarize, reducing the progressivity in the Swedish tax system has considerable welfare effects. The difference in these effects between poor households and rich households is substantial. The effect on working hours is quite small and there will be a sharp decline in tax revenues.

\section{Conclusions}

In this paper, we used a sample of Swedish households with detailed information on incomes and benefits and estimated a structural household labor supply model. We formulated a model where labor supply and participation in welfare programs were jointly determined. Further, the labor supply and welfare participation decisions were treated as a discrete choice problem, and we assumed that these choices follow a simple conditional logit rule. We used a micro simulation model to evaluate consumption bundles at different hours of work combinations. In addition, we allowed for unobserved individual-specific effects and also for these effects to be correlated across alternatives. The unobserved effects were assumed to be drawn from a discrete distribution, and the correlation across alternatives was modeled using 
factor-loading techniques. Classification error in hours was allowed for by using a multiplicative measurement error specification.

The estimates from the structural model yielded small wage and income elasticities, especially for the husbands. A tax simulation showed that reducing the progressivity in the Swedish tax system may have considerable welfare effects. It also showed that these effects might differ substantially between poor households and rich households. Finally, the effect on working hours from the reform was quite small and tax revenues were predicted to drop significantly. 


\section{References}

Andersson, P.A., Flood, L.R. and Hansen J., 1993, "Measurement of variables in the Study of Labor Supply. A comparison and evaluation of alternative methods," Memorandum 198, Department of Economics, University of Göteborg.

Blundell, R. Duncan, A., MacCrae, J. and Meghir, C., 1999, "Household Labour Supply, Childcare Costs and Tax Credits," working paper, Presented at the workshop "The Economics of Childcare," held at IZA in November 1999.

Deb, P. and Trivedi, P.K., 1997, "Demand for medical care by the elderly: A finite mixture approach," Journal of Applied Econometrics 12, 313-336.

Ham, J. and Lalonde, R., 1996, "The effects of Sample Selection and Initial Conditions in Duration Models: Evidence from Experimental Data on Training," Econometrica 64, 175-205.

Heckman, J. and Singer, B.L., 1984, "A method for minimizing the distributional assumptions in econometric models for duration data," Econometrica 52, 271-320.

Hoynes H.W., 1996, "Welfare Transfers in Two-Parent Families: Labor Supply and Welfare Participation under AFDC-UP”, Econometrica 64, 295-332.

Kapteyn, A, Kooreman, P and van Soest, A., 1990, "Quantity Rationing and Concavity in a Flexible Household Labor Supply Model." Review of Economics and Statistics 70(1), 55-62

Keane, M. and Moffitt, R., 1998, "A structural Model of Multiple Welfare Program Participation and Labour Supply," International Economic Review Vol. 39, No. 3.

MaCurdy, T., Green, D., and Paarsch, H., 1990, "Assessing empirical approaches for analyzing taxes and labor supply," Journal of Human Resources 25, 415-490.

Moffit, R., 1983, "An Economic Model of Welfare Stigma", American Economic Review 73, 1023-1035.

van Soest, A., 1995, "Structural Models of Family Labor Supply," Journal of Human Resources 30, 63-88.

Strom, S, Aaberge, R and Colombino,U., 1999, "Labor Supply Responses and Welfare Effects from Replacing Current Tax Rules by a Flat Tax: Empirical Evidence from Italy, Norway,Sweden", forthcoming Journal of Population Economics 


\section{Appendix}

Figure 1. Household budget sets.

\section{Low Income}

Husband: $\mathrm{W}=92 \mathrm{kr} / \mathrm{h}, \mathrm{Y}=0 \mathrm{kr}, \mathrm{V}=15120 \mathrm{kr}$
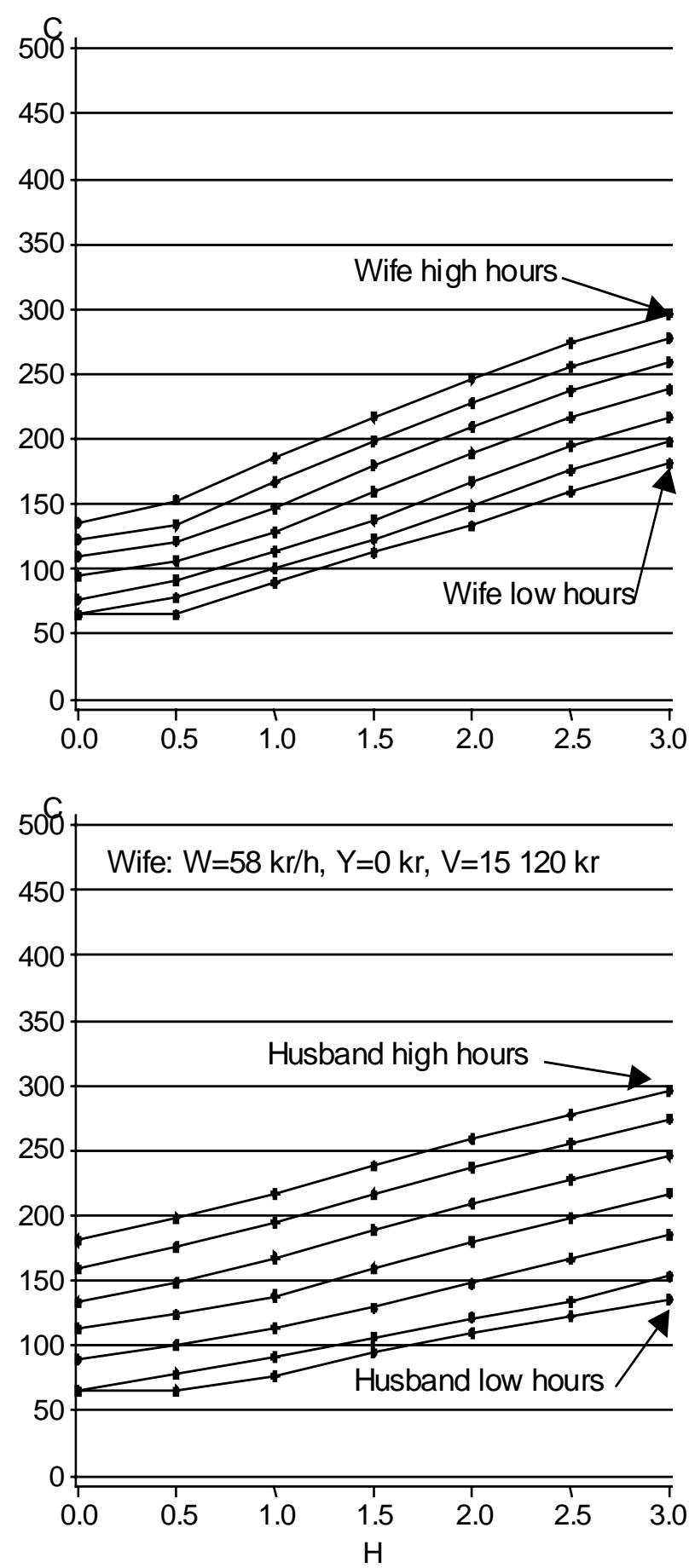

High Income

Husband: $\mathrm{W}=126 \mathrm{kr} / \mathrm{h}, \mathrm{Y}=15200 \mathrm{kr}, \mathrm{V}=28050 \mathrm{kr}$ $\mathrm{C}$
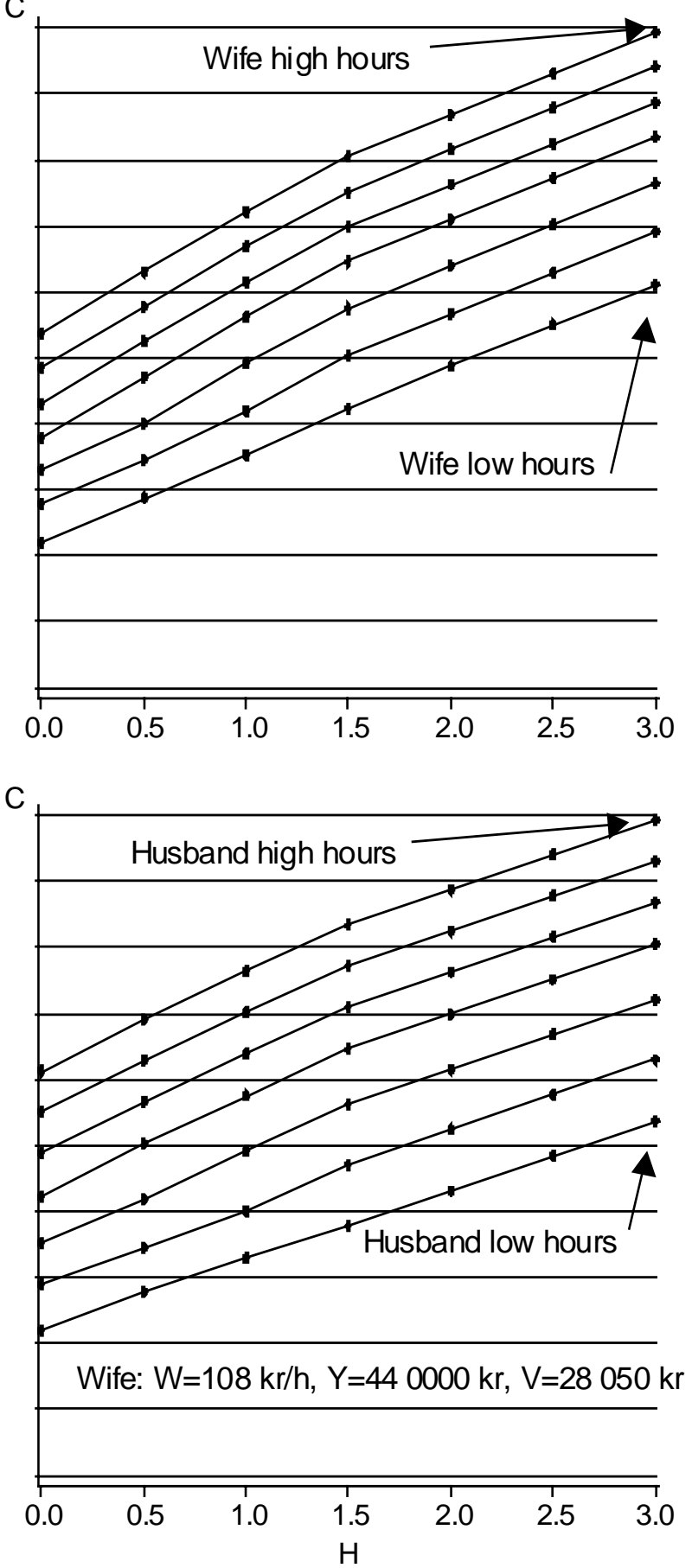
Figure 2. Marginal and average tax rates 1993

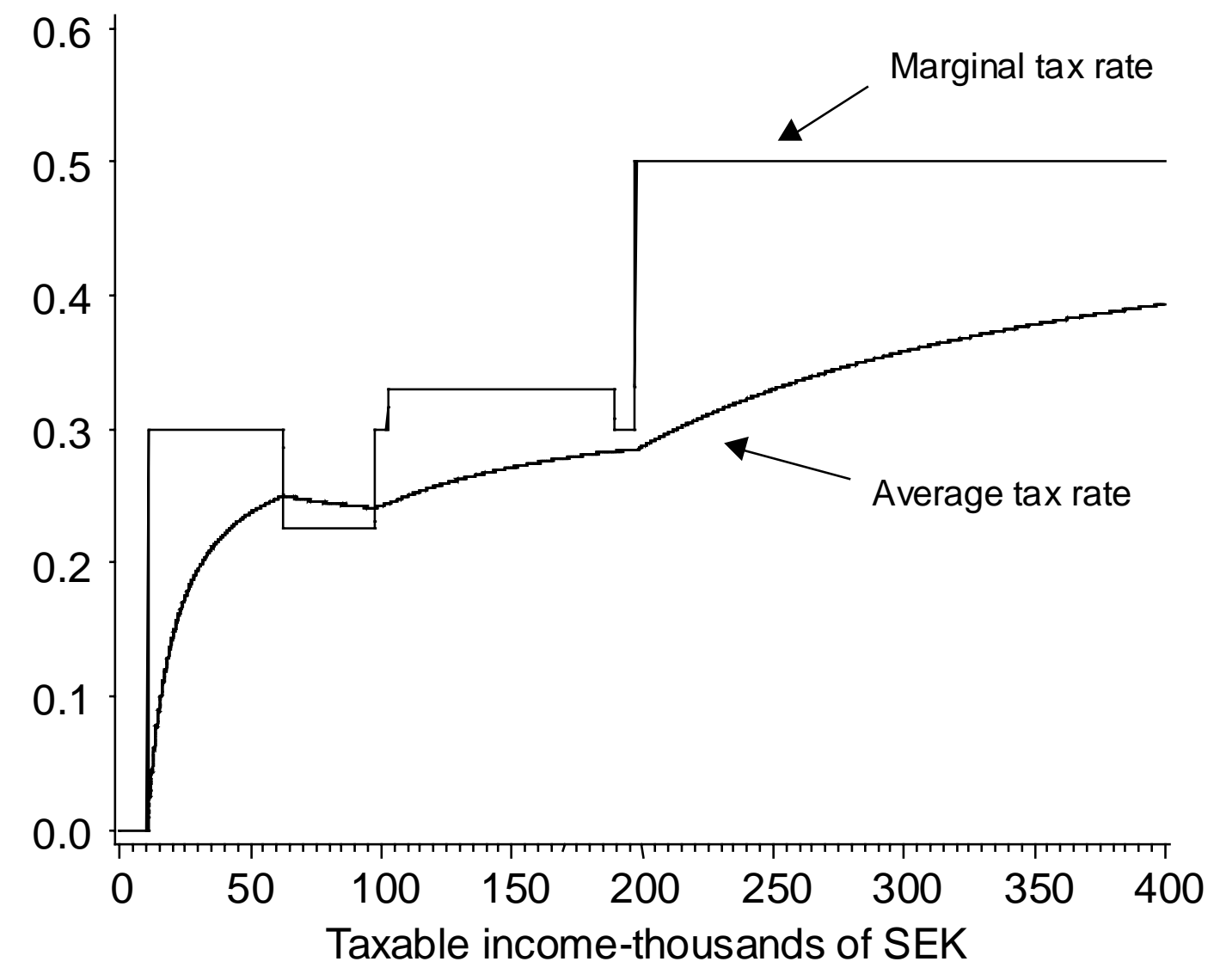


Figure 3. Observed and predicted hours of work

Husband observed

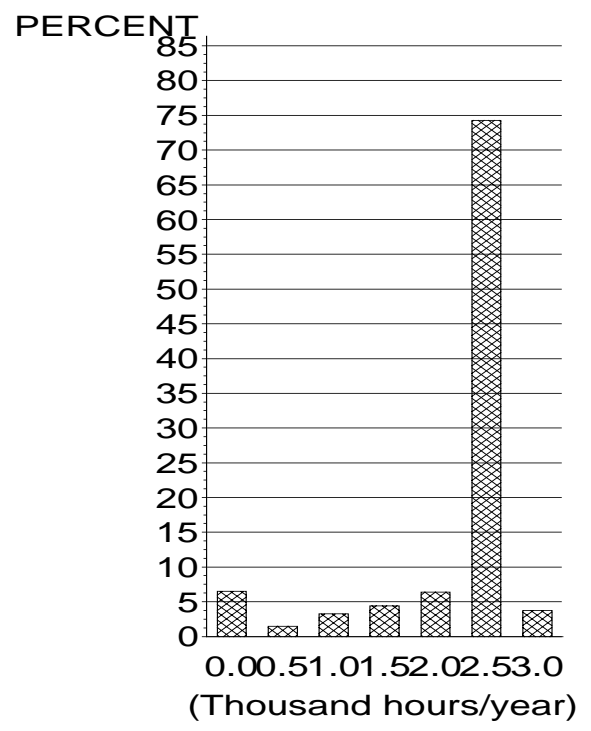

Wife observed

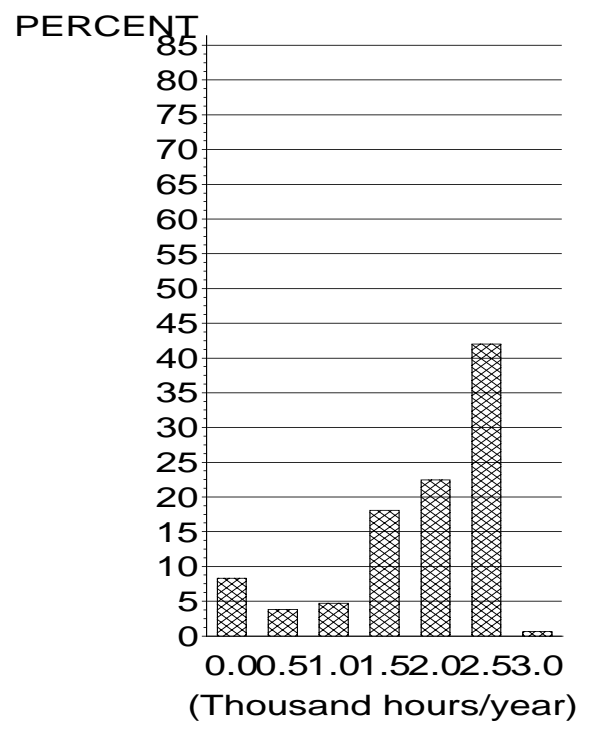

\section{Husband predicted}

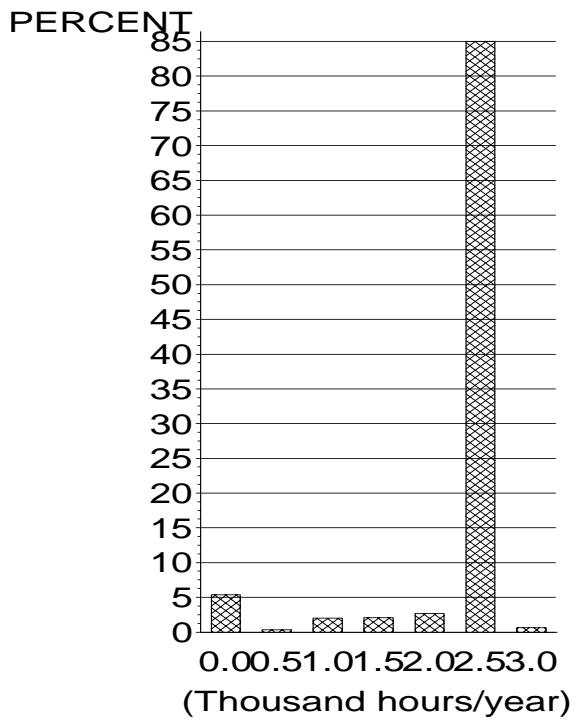

Wife predicted

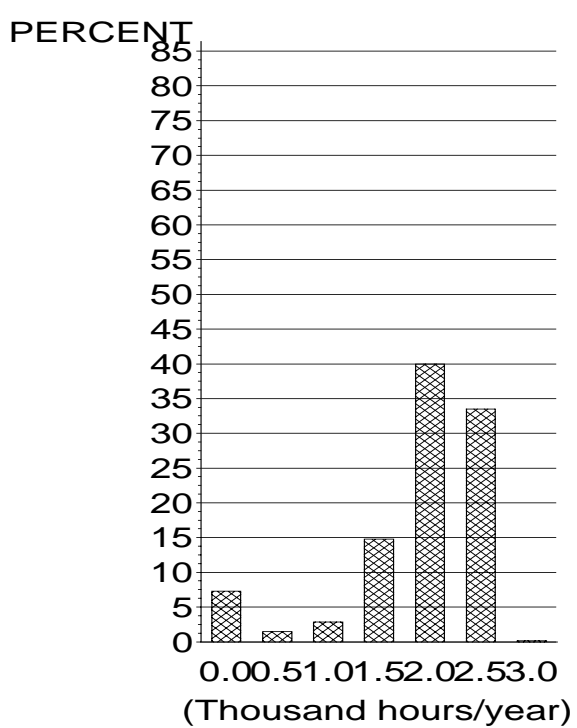


Table 1. Sample Statistics of variables used for estimation.

\begin{tabular}{|c|c|c|c|}
\hline Variables & Mean & Minimum & Maximum \\
\hline \multicolumn{4}{|l|}{ Husband: } \\
\hline Age & 43 & 20 & 64 \\
\hline Education, primary $1=y e s, 0=$ no & 0,27 & 0 & 1 \\
\hline Education highschool $1=y e s, 0=$ no & 0,57 & 0 & 1 \\
\hline Education university $1=y e s, 0=$ no & 0,16 & 0 & \\
\hline Working hours per year & 1845 & 0 & 4320 \\
\hline Working $1=$ yes, $0=$ no & 0,94 & 0 & 1 \\
\hline Wage/hour SEK & 119 & 11 & 483 \\
\hline Taxable non-labor income SEK per year & 17204 & 0 & 687500 \\
\hline Non-taxable non-labor income SEK per year & 17411 & 0 & 938930 \\
\hline Deductions SEK per year & 6979 & 0 & 134500 \\
\hline \multicolumn{4}{|l|}{ Wife: } \\
\hline Age & 40 & 18 & 64 \\
\hline Education, primary $1=y e s, 0=$ no & 0,26 & 0 & \\
\hline Education highschool $1=y e s, 0=$ no & 0,60 & 0 & \\
\hline Education university $1=$ yes, $0=$ no & 0,14 & 0 & 1 \\
\hline Working hours per year & 1520 & 0 & 3024 \\
\hline Working $1=y e s, 0=$ no & 0,92 & 0 & \\
\hline Wage/hour SEK & 91 & 13 & 481 \\
\hline Taxable non-labor income SEK per year & 13714 & 0 & 291218 \\
\hline Non-taxable non-labor income SEK per year & 10584 & 0 & 603050 \\
\hline Deductions SEK per year & 4208 & 0 & 146200 \\
\hline \multicolumn{4}{|l|}{ Household: } \\
\hline Number of children $0-18$ years old & 1,01 & 0 & 6 \\
\hline Children $<7$ years old $1=$ yes, $0=$ no & 0,30 & 0 & 1 \\
\hline Large cities $1=y e s, 0=$ no & 0,42 & 0 & 1 \\
\hline Medium cities $1=y e s, 0=$ no & 0,44 & 0 & . \\
\hline Country side $1=y e s, 0=$ no & 0,14 & 0 & 1 \\
\hline Welfare $1=y e s, 0=$ no & 0,03 & 0 & \\
\hline
\end{tabular}


Table 2. Estimates of the parameters of the utility function.

\begin{tabular}{|c|c|c|c|c|c|}
\hline Variables & Coefficient & Estimates & $\begin{array}{r}\text { Standard } \\
\text { errors }\end{array}$ & Estimates & $\begin{array}{r}\text { Standard } \\
\text { errors }\end{array}$ \\
\hline \multicolumn{6}{|l|}{ Husband: } \\
\hline Number of children, $0-18$ years old & $\beta_{\mathrm{h} 1}$ & $-0,1068$ & 0,1797 & $-0,0879$ & 0,1789 \\
\hline Children $<7$ years old, $1=$ yes, $0=$ no & $\beta_{\mathrm{h} 2}$ & 0,1929 & 0,4424 & 0,1249 & 0,4428 \\
\hline Region small cities, $1=y e s, 0=$ no & $\beta_{\mathrm{h} 3}$ & $-0,6909$ & 0,3340 & $-0,7762$ & 0,3352 \\
\hline Region country side, $1=y e s, 0=$ no & $\beta_{\mathrm{h} 4}$ & $-0,9892$ & 0,4938 & $-1,1572$ & 0,4979 \\
\hline Education highschool, $1=y e s, 0=$ no & $\beta_{\mathrm{h} 5}$ & 0,3286 & 0,3605 & 0,3250 & 0,3626 \\
\hline Education university, $1=$ yes, $0=$ no & $\beta_{\mathrm{h} 6}$ & 1,3402 & 0,5421 & 1,4648 & 0,5442 \\
\hline Age $18-34,1=y e s, 0=$ no & $\beta_{\mathrm{h} 7}$ & $-3,8590$ & 0,6437 & $-3,7335$ & 0,6361 \\
\hline Age $35-44,1=y e s, 0=$ no & $\beta_{\mathrm{h} 8}$ & $-3,8188$ & 0,5907 & $-3,7561$ & 0,5860 \\
\hline Age $45-54,1=y e s, 0=$ no & $\beta_{\mathrm{h} 9}$ & $-3,4403$ & 0,5185 & $-3,3330$ & 0,5168 \\
\hline \multicolumn{6}{|l|}{ Wife: } \\
\hline Number of children, $0-18$ years old & $\beta_{\mathrm{w} 1}$ & 0,7391 & 0,1094 & 0,7081 & 0,1081 \\
\hline Children $<7$ years old, $1=$ yes, $0=$ no & $\beta_{\mathrm{w} 2}$ & 1,1295 & 0,2574 & 1,0867 & 0,2545 \\
\hline Region small cities, $1=y e s, 0=$ no & $\beta_{\mathrm{w} 3}$ & 0,5469 & 0,1957 & 0,4997 & 0,1937 \\
\hline Region country side, $1=$ yes, $0=$ no & $\beta_{\mathrm{w} 4}$ & 0,3419 & 0,2708 & 0,2595 & 0,2693 \\
\hline Education highschool, $1=y e s, 0=$ no & $\beta_{\mathrm{w} 5}$ & $-0,2384$ & 0,1931 & $-0,2603$ & 0,1907 \\
\hline Education university, $1=y e s, 0=$ no & $\beta_{\mathrm{w} 6}$ & $-1,2079$ & 0,3142 & $-1,1289$ & 0,3090 \\
\hline Age $18-34,1=$ yes, $0=$ no & $\beta_{\mathrm{w} 7}$ & $-2,6098$ & 0,3677 & $-2,4517$ & 0,3612 \\
\hline Age $35-44,1=y e s, 0=$ no & $\beta_{\mathrm{w} 8}$ & $-2,4072$ & 0,3533 & $-2,2994$ & 0,3464 \\
\hline Age $45-54,1=y e s, 0=$ no & $\beta_{\mathrm{w} 9}$ & $-1,5706$ & 0,3187 & $-1,4910$ & 0,3113 \\
\hline Consumption & $\beta_{\mathrm{C}}$ & 26,3712 & 2,4760 & 34,3589 & 3,5144 \\
\hline Consumption squared & $\beta_{\mathrm{CC}}$ & 1,8999 & 0,2659 & $-0,5574$ & 1,1220 \\
\hline Husband hours squared & $\beta_{\text {hh }}$ & $-19,0994$ & 0,5866 & $-19,4239$ & 0,6210 \\
\hline Wife hours squared & $\beta_{w w}$ & $-4,8509$ & 0,5192 & $-4,7572$ & 0,5495 \\
\hline Husband hours times consumption & $\beta_{\mathrm{Ch}}$ & $-3,4284$ & 0,6020 & $-4,4276$ & 0,6908 \\
\hline Wife hours times consumption & $\beta_{\mathrm{Cw}}$ & $-3,0283$ & 0,4030 & $-3,7752$ & 0,4652 \\
\hline Husband hours times wife hours & $\beta_{\mathrm{hw}}$ & $-1,9044$ & 0,4256 & $-2,1538$ & 0,4286 \\
\hline Classification error, Husband & $\varepsilon_{\mathrm{h}}$ & 0,1226 & 0,0015 & 0,1226 & 0,0015 \\
\hline Classification error, Wife & $\varepsilon_{\mathrm{w}}$ & 0,1520 & 0,0019 & 0,1520 & 0,0019 \\
\hline \multirow[t]{4}{*}{ Heterogeneity, Husband: } & $\theta_{\mathrm{h} 1}$ & 68,9429 & 2,7163 & 71,2041 & 2,8480 \\
\hline & $\theta_{\mathrm{h} 2}$ & 34,0377 & 2,4618 & 37,0788 & 2,6251 \\
\hline & $\theta_{\mathrm{h} 3}$ & 36,9811 & 2,6640 & 39,9292 & 2,8111 \\
\hline & $\theta_{\mathrm{h} 4}$ & 87,5092 & 4,1612 & 94,8965 & 4,8837 \\
\hline \multirow[t]{4}{*}{ Heterogeneity, Wife: } & $\theta_{\mathrm{w} 1}$ & 23,4670 & 1,8225 & 25,5678 & 1,9445 \\
\hline & $\theta_{\mathrm{w} 2}$ & 22,3290 & 1,6089 & 24,3638 & 1,7588 \\
\hline & $\theta_{\mathrm{w} 3}$ & 42,5382 & 2,2078 & 45,0012 & 2,4058 \\
\hline & $\theta_{\mathrm{w} 4}$ & 39,2382 & 2,0893 & 43,1125 & 2,8941 \\
\hline \multirow[t]{4}{*}{ Heterogeneity Probabilities: } & $\pi_{1}$ & 0,1155 & 0,0060 & 0,1196 & 0,0062 \\
\hline & $\pi_{2}$ & 0,7830 & 0,0087 & 0,7861 & 0,0087 \\
\hline & $\pi_{3}$ & 0,0664 & 0,0070 & 0,0628 & 0,0068 \\
\hline & $\pi_{4}$ & 0,0350 & -------- & 0,0315 & - \\
\hline \multicolumn{6}{|l|}{ Welfare participation: } \\
\hline Constant & $\mu$ & 6,8488 & 0,5369 & -------- & $-\cdots--\cdot$ \\
\hline Covariance husband hours, welfare & $\sigma_{\mathrm{h}}$ & $-0,0406$ & 0,0064 & -------- & ------ \\
\hline Covariance wife hours, welfare & $\sigma_{\mathrm{w}}$ & $-0,0502$ & 0,0202 & -------- & $----\cdot$ \\
\hline Log of Likelihood Function & & \multicolumn{2}{|c|}{-5350.59} & \multicolumn{2}{|c|}{-4970.66} \\
\hline
\end{tabular}


Table 3. Change in working hours as wage and income change $1 \%$.

\begin{tabular}{|l|c|c|}
\hline & $\begin{array}{c}\text { Male hours } \\
\text { Percentage } \\
\text { change }\end{array}$ & $\begin{array}{c}\text { Female hours } \\
\text { Percentage } \\
\text { change }\end{array}$ \\
\hline Male wage increase 1\% & 0 & $-0,021$ \\
\hline Female wage increase 1\% & 0 & 0,120 \\
\hline $\begin{array}{l}\text { Household non-labor } \\
\text { income increase 1\% }\end{array}$ & $-0,003$ & -0.017 \\
\hline
\end{tabular}

Table 4. Tax simulation: Before and after tax changes for the whole sample

\begin{tabular}{|l|r|r|r|r|}
\hline & \multicolumn{1}{|c|}{ Mean } & Minimum & Maximum & \multicolumn{1}{|l|}{ Variance } \\
\hline Husband: & & & & \\
\hline Working hours before tax change & 2063 & 0 & 2750 & 322 \\
\hline Working hours after tax change & 2068 & 0 & 2750 & 322 \\
\hline Wife: & & & & 400 \\
\hline Working hours before tax change & 1667 & 0 & 2750 & 415 \\
\hline Working hours after tax change & 1694 & 0 & 2750 & \\
\hline Household: & & & & 13651111 \\
\hline Disposable income before tax change & 337256 & 54403 & 1569437 & 136518 \\
\hline Disposable income after tax change & 362877 & 54403 & 1794373 & 20856518 \\
\hline Taxes paid before tax change & 99975 & 0 & 830860 & 4514474 \\
\hline Taxes paid after tax change & 86198 & 0 & 551270 & 2168040 \\
\hline Equivalent variation & 25200 & 0 & 423374 & 1045561 \\
\hline
\end{tabular}

Table 5 Tax simulation: Equivalent variation for different income levels

\begin{tabular}{|l|r|r|r|r|}
\hline & Mean & Minimum & Maximum & Variance \\
\hline Poorest 10:th percent & 6455 & 0 & 113066 & 187072 \\
\hline Poorest 25:th percent & 4924 & 0 & 113066 & 114476 \\
\hline Below the median & 7610 & 0 & 113066 & 112876 \\
\hline Richest 25:th percent & 63224 & 0 & 423374 & 1710815 \\
\hline Richest 10:th percent & 90510 & 291 & 423374 & 2563024 \\
\hline
\end{tabular}


Table 6. Wage rates and participation equation.

\begin{tabular}{|c|c|c|}
\hline Variables & Estimates & Standard errors \\
\hline $\begin{array}{l}\text { Participation equation; Husband } \\
\text { :Constant }\end{array}$ & $-2,1974$ & 0,3197 \\
\hline Number of children, $0-18$ years old & 0,0116 & 0,0512 \\
\hline Children $<7$ years old, $1=$ yes, $0=$ no & $-0,0620$ & 0,1288 \\
\hline Region small cities, $1=y e s, 0=$ no & $-0,1553$ & 0,0809 \\
\hline Region country side, $1=y e s, 0=$ no & $-0,1873$ & 0,1099 \\
\hline Education highschool, $1=$ yes, $0=$ no & 0,4009 & 0,0768 \\
\hline Education university, $1=y e s, 0=$ no & 1,3175 & 0,1799 \\
\hline Age $18-34,1=$ yes, $0=$ no & 2,7525 & 0,2554 \\
\hline Age $35-44,1=$ yes, $0=$ no & 1,8676 & 0.1953 \\
\hline Age $45-54,1=$ yes, $0=$ no & 1,0188 & 0,1322 \\
\hline Years of experience & 0,1346 & 0,0172 \\
\hline Years of experience squared & $-0,1533$ & 0,0302 \\
\hline \multicolumn{3}{|l|}{ Log wage rate equation: Husband } \\
\hline Constant & 4,7614 & 0,1528 \\
\hline Number of children, $0-18$ years old & 0,0069 & 0,0074 \\
\hline Region small cities, $1=y e s, 0=$ no & $-0,1145$ & 0,0158 \\
\hline Region country side, $1=y e s, 0=$ no & $-0,1527$ & 0,0221 \\
\hline Education highschool, $1=y e s, 0=$ no & 0,1191 & 0,0218 \\
\hline Education university, $1=y e s, 0=$ no & 0,3703 & 0,0399 \\
\hline Age $18-34,1=$ yes, $0=$ no & $-0,3592$ & 0,0970 \\
\hline Age $35-44,1=$ yes, $0=$ no & $-0,2600$ & 0,0720 \\
\hline Age $45-54,1=y e s, 0=$ no & $-0,1405$ & 0,0490 \\
\hline Years of experience & 0,0132 & 0,0053 \\
\hline Years of experience squared & $-0,0301$ & 0,0085 \\
\hline$\lambda$ & $-0,2889$ & 0,1530 \\
\hline Participation equation; Wife: Constant & $-2,2067$ & 0,1934 \\
\hline Number of children, $0-18$ years old & $-0,0448$ & 0,0089 \\
\hline Children $<7$ years old, $1=$ yes, $0=$ no & $-0,1943$ & 0,1251 \\
\hline Region small cities, $1=y e s, 0=$ no & 1,4872 & 0,1466 \\
\hline Region country side, $1=y e s, 0=$ no & 0,9429 & 0,1159 \\
\hline Education highschool, $1=y e s, 0=$ no & 0,2966 & 0,0757 \\
\hline Education university, $1=y e s, 0=$ no & 0,8339 & 0,1481 \\
\hline Age $18-34,1=$ yes, $0=$ no & 2,7294 & 0,1739 \\
\hline Age $35-44,1=$ yes, $0=$ no & 1,4818 & 0,1466 \\
\hline Age $45-54,1=$ yes, $0=$ no & 0,9429 & 0,1159 \\
\hline Years of experience & 0,2045 & 0,0136 \\
\hline Years of experience squared & $-0,3365$ & 0,0290 \\
\hline \multicolumn{3}{|l|}{ Log wage rate equation: Wife } \\
\hline Constant & 4,2778 & 0,1054 \\
\hline Number of children, $0-18$ years old & 0,0140 & 0,0070 \\
\hline Region small cities, $1=y e s, 0=$ no & $-0,0582$ & 0,0140 \\
\hline Region country side, $1=y e s, 0=$ no & $-0,0916$ & 0,0202 \\
\hline Education highschool, $1=y e s, 0=$ no & 0,0480 & 0,0169 \\
\hline Education university, $1=y e s, 0=$ no & 0,2656 & 0,0261 \\
\hline Age $18-34,1=y e s, 0=$ no & $-0,0365$ & 0,0664 \\
\hline Age $35-44,1=$ yes, $0=$ no & $-0,0157$ & 0,0463 \\
\hline Age $45-54,1=y e s, 0=$ no & 0,0321 & 0,0365 \\
\hline Years of experience & 0,0113 & 0,0051 \\
\hline Years of experience squared & $-0,0195$ & 0,0097 \\
\hline$\lambda$ & 0,0757 & 0,0893 \\
\hline
\end{tabular}

